\title{
Improving students' reading comprehension on procedure text by using demonstration method at grade IX A SMPN 1 Kerinci in first semester of 2017/2018 academic year
}

\author{
Irzal Wadi ${ }^{1}$, Mukhaiyar Mukhaiyar' ${ }^{2}$, Hamzah Hamzah ${ }^{3}$ \\ ${ }^{123}$ Universitas Negeri Padang, Padang - Indonesia, (irzalwadikerinci@gmail.com)
}

\begin{abstract}
This research is designed to improve the students' reading comprehension on procedure text by using demonstration method. This is aimed at finding whether demonstration method can improve students' reading comprehension on procedure text at Grade IX A SMPN 1 Kerinci in First Semester of 2017/2018 Academic Year. The study employed a classroom action research design in which the researcher and his collaborator worked together in designing the lesson plan, implementing the action, analyzing the data, and doing the reflection. The participants of this research were 23 students at Grade IX A SMPN 1 Kerinci in First Semester of 2017/2018 Academic Year. The research finding was that demonstration method could improve the students' reading comprehension. This conclusion was based on the increasing of the average score of students' reading comprehension. The students' average score before conducting the method was only 57,39 , then it increased to 73,04 in cycle one. And it became 77,82 in cycle two. It means that students' average score successively improved in each cycle. And it can achieve the minimum achievement criteria or KKM, 70. Furthermore, factors that influence teaching and learning process are material, media, classroom activity, classroom management, teacher's approach, and teaching strategy.
\end{abstract}

Keywords: reading comprehension, procedure text, demonstration method

\section{Introduction}

In English subject, there are some skills that should be mastered and possessed by students. They are speaking, reading, writing, and listening. Reading is one of more important skills taught at school. By comprehending the reading materials, the students are able to understand what they have read as well as they can recall and restate the text after reading.

The ability in comprehending the texts needs to be applied and generalized in various settings within academic and later in life. When the students are able to comprehend the texts, they gain meaning from the texts. 
In addition, reading is necessary to get information and improve students' English skills. Since it is important, students' reading improvement should become a priority. Therefore, teaching reading at school is also a main part of teaching and learning process. In other word, teaching reading is mostly taking part in English subject at school.

However, during the writer's prior observation towards the teaching of reading, it is commonly hard for the students to grasp as well as to understand the text that they have read. Moreover, there are many problems dealing with reading comprehension. They are lack of vocabularies, reading materials are not contextual or relevant with the students' circumstances, students' low motivation, and less strategies or techniques applied by the teachers in teaching reading.

In addition, based on the result of reading comprehension test which was conducted by the writer toward grade IX A SMPN 1 Kerinci which consists of 23 students, it was found that only 3 students got score above 70 and 20 students got score below 70 . In this grade, the minimum achievement criteria was 70 . It meant that the result of the test showed that only three students $(13,04 \%)$ got score above 70 . The rest of them, twenty students $(86,96 \%)$, got score below 70 . In other words, only 3 students got score above the minimum achievement criteria, 70. And 20 students got score below the minimum achievement criteria. In short, mostly students had difficulty in comprehending English text.

Therefore, in order to improve the students' reading comprehension, English teachers should apply some strategies or techniques in their teaching and learning process. In line with these points, there are a number of techniques that can be implemented by the English teachers in teaching reading. Some of them are Guided Reading, S-RUN-R, Intensive Reading, Paraphrasing, SQ3R, and Demonstration method. In this research, the writer wants to apply demonstration method in teaching reading, especially reading procedure text. Since procedure text is a kind of text that explains how to do, how to make, and how to act a certain thing in a sequence of event, the writer assumes that the demonstration method is a suitable and appropriate method used in teaching procedure text.

Based on the explanation above, the writer wants to apply the demonstration method in teaching reading at First Semester of 2017/2018 academic year of grade IX A SMP Negeri 1 Kerinci Jambi. The type of reading text which is going to be used by the writer is procedure texts. Revealing all of these, the writer is interested to carry out a research entitled "Improving Students' Reading Comprehension on Procedure Text by Using Demonstration Method at Grade IX A SMPN 1 Kerinci in First Semester of 2017/2018 Academic Year".

There are a number of definitions and theories about reading. According to Ling (2012:147) "reading is getting the text into the correct meaning". In this case, the readers have to observe, interprete, and evaluate the printed pages. It is a complex activity that involves both perception and thought. It consists of two related processes: word recognition and comprehension.

In addition, Gibgons (1991:51) states that " reading is process of getting meaning from print". It means there is interaction between the author and the reader in this activity because the writer delivers her/his idea to the readers through the texts. The readers can also improve their understanding through reading activity.

Based on the opinion above, it can be summarized that reading is an interaction and a thinking process of transferring printed letters into meaning in communicating of message between the writer and the reader. It means that readers have to discover ideas from the text based on their background knowledge about the texts.

In reading, comprehension is a crucial thing. It is a process of constructing meaning from the text. And it is not only understanding the words in sentence but also understanding the whole writings are going to the writer's mind when to write the words. It is supported by Cooper (2000:12) who states 
that "comprehension is a process in which the readers may construct meaning by interacting with the text." Moreover, Grellete (1999:3) says that "comprehension means understanding a written text which takes the information out from it as efficiently as possible."

In addition, according to Zainil (2005) "to understand paragraph involves the process in identifying the paragraph elements such as: topic, main idea, details of paragraph, and references." The topic is the word or phrase as subject of paragraph and answer of the question "what is the whole paragraph about". While, main idea is the sentence that states topic of paragrapah. It is the answer of the question "what does the author say about the topic of paragraph." In short, when the students have the abilities in identifying the elements of the passage, it means they find the essential information in the text.

Here, therefore, the researcher takes some reading comprehension indicators from of several theories above, they are determining the topic or main idea of the text, determining the specific information, determining the meaning of words or sentences in the text, and determining reference of pronoun.

In this research, the researcher uses multiple choice questions for reading test based on the indicators of reading comprehension of procedure text.

The aim of procedure text is to give a guidance about steps, methods, and ways of doing something (Djuharie, 2006:38). Usually, procedure text contains tips or a sequence of actions as well as steps in making something or doing certain activities. In other words, procedure text is a text that is designed to describe how something is achieved through a sequence of actions or steps. In addition, it has generic structure. They are the goal of activity, materials, steps to achieve the goal, and conclusion. Moreover, it also has specific linguistic features. They are imperatives, action verbs, connectives, adverbials or temporal conjunctions, and using simple present tense.

Moreover, Knapp and Watkins (2005:155-158) state that in procedure text one of the early cognitive skills children develop is the ability to sequence. However, many children flounder when they are expected to reproduce a sequence of step in writing. For this reason it is important to use concrete activities when first working with instructing and to represent stages in a procedure pictorially. Furthermore, they also say that the texts also indicate an ability to deal with aspects of the grammar of instructing, such as the processes involved in each step, represented by action verbs, and the temporal nature of the sequencing, represented in the grammar by temporal connectives.

Demonstration method is a method that is used in teaching and learning process by demonstrating some objects or actions in order to make a lesson or a study clearer and easier for students to understand. According to Syah (1995:201), demonstration method is a method of teaching by showing objects, events, rules, and orders of doing something.

In conducting the demonstration method, there are some steps of implementation. The first one is preparation phase, in this phase, there are some activities that should be done. They are formulating the goal or aim that the students should master after doing the activities, preparing the outline of the demonstration steps that will be done. The second one is implementation phase, it consists of opening step, implementing step, and ending step.

There are some factors that affect the teaching and learning process in the classroom. According to Yasin (2011:77), some factors that influence students' achievement in teaching and learning process are teaching material, media, classroom activity, classroom management, teacher's approach, and teaching strategy. Therefore, the success of teaching and learning process depends on material, media, classroom activity, classroom management, teacher's approach, and teaching strategy.

Then, the influences of these factors in learning reading comprehension can be seen through observation, interview, and field note. 


\section{Method}

This study employs a classroom action research. Classroom action research concerned with trying to improve one specific point in a teacher's strategy in a particular classroom using empirical measurement.

In this research, the researcher implemented the cycle process which consists of three meetings for the first cycle and three meetings in the second cycle. Each meeting took two hours ( 2 X 40 minutes). The researcher made the target about the cycle for two cycles. It was assumed that students' reading comprehension on procedure text can be improved by using demonstration method.

The participants of this research are the students of grade IX SMP Negeri 1 Kerinci in First Semester of 2017/2018 academic year. There are seven classes of grade IX SMP Negeri 1 Kerinci. The researcher takes one class as participants of this research, that is IX A. It is taken because the researcher teaches English in this class. The students of IX A consits of 23 students, 5 males and 18 females.

This research covers two kinds of data, they are quantitative data and qualitative data. The quantitative data were taken from tasks and tests. These data were represented by students' ability in comprehending indicators of reading comprehension on procedure text. While qualitative data concerns with the description about factors that influence the changes of students' English reading comprehension on procedure texts by using demonstration method. It can be described by using of material, media, classroom activities, classroom management, teacher's approach, and teaching strategy in this research.

The researcher used some instruments to get the data. In this research, researcher was the key instrument. In addition, instruments for collecting data are task and test, observation (field notes, observation checklist), and interview.

To assess the students' reading comprehension in every single day in order to have comparison with the score result in the test, the researcher uses task. Later on, he got description of the students whether they have good progress or not in each meeting. Hence, the researcher is able to see the process of conducting demonstration method in this research.

The question sheet of task is related to some topics in procedure text, here the topics are " how to make instant fried noodle", " how to get an egg into a bottle", "to find things that dissolve in water", and "beneficial magnet", so the teacher will demonstrate these topics by showing or demonstrating the steps or the process of " how to make instant fried noodle", " how to get an egg into a bottle", "to find things that dissolve in water", and "beneficial magnet". The students observe or see this process while comprehending the text. Then, the students are asked to reread and to recomprehend the text comprehensively. Finally, they are asked to do and to answer the questions of tasks given.

Moreover, the researcher used test to collect the data about students' ability in comprehending reading text of procedure. The tests were in form of reading texts which the students given some topics of procedure text based on the curriculum and teaching materials. The test was constructed in multiple choice form. The students answered the questions according to the instruction given. The test items were developed by considering the indicators of reading comprehension on procedure text and consulting with the researcher's advisors and experts. Then, to achieve the validity and reliability of the tests, the researcher applied the Pearson Product Moment Correlation formula. Therefore, the researcher tried 'the test' out firstly. After conducting and analyzing the validity and reliability of the test, it found that the correlation coefficient of test of cycle one was 0,8641. It meant that the validity and reliability of the test in cycle one was high. Then, the correlation coefficient of test of cycle two was 0,936 . It also meant that the validity and reliability of the test in cycle two was high. After that, the tests were given to the students at the end of every cycle. 
The next instrument is observation checklist. The researcher uses observation guideline to diagnose the problems on reading activity of procedure text. In observation, he uses observation checklist marked by the collaborator to note the teacher's and students' activities. It is prepared before conducting the research. These observation instruments are noted by other English teacher as a collaborator. The result of observation was used to know whether the teacher implemented demonstration method or not in teaching reading of procedure text and students' activities in reading comprehension of procedure text.

Observation checklist on teaching reading comprehension by using demonstration method was used to observe the teaching and learning process which was taken from the lesson plan. It explained whether or not the teacher did the steps of teaching well and completely. Moreover, it was used to observe the factors that influence the teaching process. This instrument was firstly validated by an expert who was an English lecturer at IAIN Kerinci. Based on his validation, it found that the instrument can be used without revision.

Then, the guided interview is used to know about the students' condition of learning and comprehending the reading text of procedure. It explained the factors that affect the students' reading comprehension. In this research, the researcher used sheet of interview. Then, this instrument was also firstly validated by an expert who was an English lecturer at IAIN Kerinci. Based on his validation, it found that the instrument can be used without revision.

The researcher divides the analysis of the data based on the category of the data: Quantitative Data Analysis, the quantitative data are obtained from the score of reading comprehension test which is analyzed by using simple quantitative data analysis. The formula as follows:

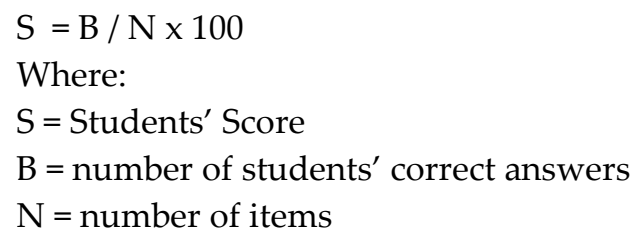

In each cycle, the scores were presented in order to know and compare students' progress from the first cycle into the next cycle. In this case, the data presented in percentage form. It was done by presenting the data in table and graph. The data were calculated by applying formula suggested by Sudjana (2006) as follows:

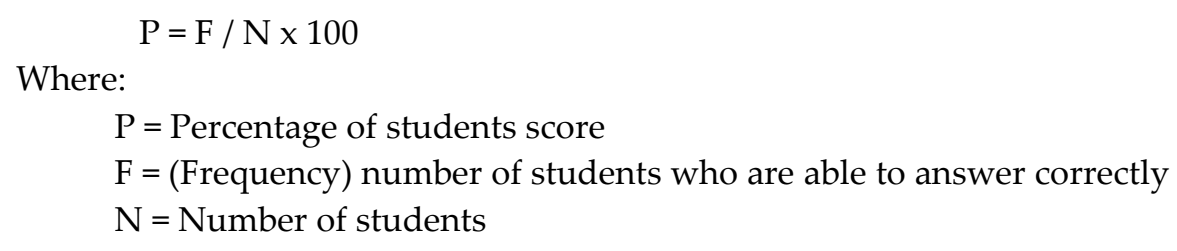

Then, the researcher calculated the students' means of reading comprehension ability based on reading comprehension indicators and presented the scores on the graphic forms. The researcher used the formula of the means offered by Gay and Airasian (2009) as follows:

$$
\begin{aligned}
X & =\frac{\sum \mathrm{x}}{\mathrm{N}} \\
\text { Note: } \mathrm{X} & =\text { means of score } \\
\sum \mathrm{X} & =\text { the sum of all scores }
\end{aligned}
$$




\section{$\mathrm{N}=$ Number of students}

Based on the result of formula above, the researcher categorizes the student's ability in comprehending reading text by comparing percentage of each cycle of the test. To display the differences clearly the researcher uses tables and graphs.

Qualitative Data Analysis, the qualitative data were analyzed by describing observation checklists, field notes, and interviews. In this research, the researcher and collaborator described the extent of demonstration method in improving students' reading comprehension at grade IX A of SMPN 1 Kerinci.

Gay and Airasian (2009:239-241) give five steps in analyzing the qualitative data. They are: Data managing; data managing involved organizing the data collected during the research activities. The data are taken from the observation, field note, and interview which will be put in a form to be analyzed. In other words, the researher needs to 'file' the data. The purpose of data managing is to organize the data and to check the completeness of the data. Reading / Memoing; in this step, the researcher reads and analyzes the data compiled deeply based on the result in the research. Description; the data taken during the research are described in detail. It describes what was going on the setting and the participants based on the observations and field notes. The aim is to provide the real situation of the activity happen in the research. Classifying; the data from the observation checklist and field notes are classified to get detail information about the participants and activity during the research.

Interpreting; the last step is interpreting. It is used to interprete the data collected into the conclusion. Interpretation leads the researcher to summarize and conclude the data.

\section{Result and Discussion}

The result of data analysis showed that the students' average score improved successively from preliminary research until the last cycle or cycle two of the research. The students' average score before applying the method was only 57,39. It increased to 73,04 in cycle one. And it became 77,82 in cycle two. Moreover, before applying the technique, only three students $(13,04 \%)$ could reach the minimum achievement criteria. While in the cycle one it increased into sixteen students $(69,56 \%)$ who could achieve the minimum achievement criteria. Then in the cycle two, there were twenty two students $(95,65 \%)$ who could reach the minimum achievement criteria. It meant that there was significant improvement gained by the students in comprehending the procedure text by using the demonstration method in the teaching and learning process.

Then, based on the result of researcher and collaborator observation, there are six factors which influence students' reading comprehension improvement. The first one is material. By choosing and giving good material to the students, they will have good motivation and interest to comprehend the text. The second one is media used in teaching and learning process. By using good and interesting media in presenting the material, the students become more focus on comprehending the text given. Then, the next two factors are classroom activity and classroom management. These factors also support and give good effect to improve students' reading comprehension. Next, the teacher's approach is also a factor that influence students' reading comprehension. The students will feel comfortable, enjoyable, and fun when teacher gives well approach. The teacher's approach helps the students to overcome their difficulty in teaching and learning process. And the last factor is teaching strategy. Teaching strategy has directed the students to get better result in comprehending the text as well as to overcome their difficulty in comprehending the text. To sum up, these six factors give much contribution to improve students' reading comprehension. 


\section{Conclusion}

Reffering to the finding and the discussion above, it can be concluded that the students' reading comprehension on procedure text can be improved by using demonstration method. And the factors that can influence the improvement are material, media, classroom activity, classroom management, teacher's approach, and teaching strategy.

The researcher suggests to the other english teachers who have the same problem to implement the demonstration method in teaching reading comprehension on procedure text and to guide students to follow all the activity in the method in order to help them improve their reading comprehension. And the researcher also suggests other English teacher to consider factors that influence teaching and learning process such as material, media, classroom activity, classroom management, teacher's approach, and teaching strategy in applying the demonstrattion method in order to get good result. Next, other researchers are advised to conduct further researchs by using the demonstration method in other relevant research fields.

\section{References}

Cooper, J.D. (2000). Literacy: Helping Children Construct Meaning (4th ed.) Boston: Houghton Mifflin. Depdiknas. (2006). Materi Pelatihan Terintegrasi Bahasa Inggris. Jakarta: Depdiknas.

Djuharie, Otong Setiawan. (2006). Macam-macam Jenis Teks. Yogyakarta: Pustaka Pelajar.

Gay, LR and Airisian. (2009). Educational Research: Competencies for the Analysis and Application. New York: Prentice Hall.

Gibgons, P. (1991). Learning to Learn in a Second Language. New York: Heinemann.

Grellet, Francois. (1999). Developing Reading Skill. Cambridge: Cambridge University Press.

Knapp, P. \& Watkins, M. (2005). Genre, Text, Grammar: Technologies for Teaching and Assessing Writing. South Wales: UNSW Press.

Ling, P. (2012). The "Whole Language" Theory and Its Application to the Teaching of English Reading. English Language Teaching. 5(3). 147-152.

Sudjana, Nana. (2006). Penilaian Hasil Proses Belajar Mengajar. Bandung: Remaja Rosda Karya.

Syah, Muhibbin. (1995). Metode Pembelajaran. Jakarta: Buku Kita.

Yasin, A. (2011). Penelitian Tindakan Kelas: Tuntunan Praktis. Padang: Bung Hatta University Press.

Zainil. (2005).Good Learner Strategies and Communicative Language Teaching. Padang: Padang State University Press. 